\title{
Promote the Process of Internationalization of Universities in China through the Spread of Chinese Learning
}

\author{
Liu Yan*, Benjamin Heisler, Xu Lu \\ College of Humanities\&Law, North China Univ. of Tech., Beijing, China \\ *Corresponding author: jljaly@163.com
}

Received November 10, 2014; Revised November 19, 2014; Accepted December 10, 2014

\begin{abstract}
This paper, mainly in the context of internationalization of education, investigates the emergence of the institute responsible for the promotion of Chinese learning internationally, compared to other language promoting institutes, it has its own special characteristics and advantages. At the same time, the spread of Chinese Learning has played a very important role in the process of internationalization of China's higher education. The spreading of languages is an important basis for the internationalization of education.
\end{abstract}

Keywords: promotion of internationalization, internationalization of education, spread of Chinese Learning

Cite This Article: Liu Yan, Benjamin Heisler, and Xu Lu, "Promote the Process of Internationalization of Universities in China through the Spread of Chinese Learning." American Journal of Educational Research, vol. 2, no. 12 (2014): 1203-1206. doi: 10.12691/education-2-12-11.

\section{Introduction}

The internationalization of education is a current trend in today's world. It has been influenced by the opening of trade in the international education market, the promotion of economic globalization and trade liberalization. Educational resources in the international community need to be allocated reasonably and regarding elements of education there needs to be more exchanges and cooperation in the international community, through these measures countries can reach a greater degree of interdependence.

In the higher education sector, the meaning of internationalization is varied. As stated by Knight (1997, p 6). Globalization is the flow of technology, economy, knowledge, people, values, ideas across borders. Globalization affects each country in a different way due to a nation's individual history, traditions, culture and priorities. Internationalization of higher education is one of the ways a country responds to the impact of globalization yet, at the same time respects the individuality of the nation.

With global economization and the new trend of industrialization of education, cooperation between China and foreign countries has substantially increased. Chinese and foreign educational institutions have through cooperative education and a co-culture approach. Many foreign educational institutions see China as a very important piece in the educational market. One after another they have made their way to China to promote their schools and recruit students. In the field of foreign language learning, there is now a great importance put on
Chinese learning. This has been called "Chinese fever" has taken the world by storm. We should recognize the importance of how to provide the best curriculum and effective learning resources to these Chinese learners, as well as to promote the understanding of Chinese society and culture. The Confucius Institute has risen to the challenge of confronting such an important task.

\section{Internationalization of Education and Spreading of Foreign Languages}

Language exchange is an important basis for the internationalization of education. Only through language exchange can the internationalization of education be realized. Language exchange in itself is an important area in the internationalization of education. The internationalization of a country's language is a part of soft power competition. In order to promote a country's own culture, many countries have attached great importance to the promotion of language.

The spreading of language refers to the promotion to help foreigners learn their language, at the same time expanding the influence of language, the ultimate aim is to promote the culture that is a part of the language. For example, in France, the purpose of Alliance Française illustrates this point clearly. It states, "The main purpose is the dissemination of French, to promote French culture. The spread of French in the world, and expand the spirit of the French ideas and influence of France, in particular the solidarity of the French living abroad and foreign friends who love France, so that they continue to maintain or promote the French language and ideas of love." 
Language to promote national institutions have a fairly long history, such as the establishment in 1936 of the British Council, from 2003 to 2004 year, the Committee of 110 countries in 220 cities to work in the 126 teaching centers for more than 50 million Professors of English, and is responsible for the dissemination of British culture and the arts. Alliance Française was founded in 1884, has been in 138 countries and regions have established 1,140 branches. Goethe Institute is Germany's largest Germanlanguage communication and promotion agencies, headquartered in Munich, was founded in 1932, there are 128 overseas branch operations around the world in 76 countries and regions. Cervantes Institute was founded in 1991, 38 branches established in 23 countries to promote a better understanding of the purpose of Spain. Japan, Korea and India also plans to promote the same way through their own language and culture.

Although many countries have a long history of spreading their own language, this is the first of its kind for China. The rapid economic development of China has received attention from around the world. Co-existing with the situation that the understanding many foreigners hold of China is one of decades ago. The goal behind the teaching of the Chinese language to people around the world is really just to give a better understanding of Chinese culture.

\section{The important institute for the Spread of Chinese Learning}

Confucius Institute is the establishment of Sino-foreign cooperative non-profit educational institution dedicated to adapt to the Chinese people all over the world to learn the needs of the peoples of the world to promote Chinese language and culture of understanding between China and countries in the world of education and cultural exchanges and cooperation, the development of China and foreign countries friendly relations and promote the development of multi-cultural world, to build a harmonious world.

Confucius Institute for Chinese and foreign language teaching and education, cultural exchanges and cooperation in the provision of a service carried out in addition to Chinese language teaching, training Chinese language teachers, to provide Chinese language teaching resources, but also to carry out the examination of Chinese and Chinese teachers qualification, along with China educational, and cultural information as well as cultural exchanges between Chinese and foreign language activities.

The Chinese nation has a long history and splendid culture, especially in today's society to Western civilization and values-led international order face many problems and challenges, many scholars and researchers to look into the East, the oldest attempt to learn from the wisdom of the East nutrition. We have to move toward the world, the world's contribution to the development of China's strength and wisdom, first of all to let the world understand China. Confucius Institute is shown to the world, "China's image." The core of Chinese culture that "Confucian culture", Confucius is the representative of Confucian culture, many foreigners think that Confucius is an important symbol of China to "Confucius" naming the name of the image of college is not only intuitive, but college will have a representative in the international arena and influence.

Facts have proved that the world is very welcome for this form. As of April 2009, Hanban has started the construction of 326 Confucius Institutes (classroom), located in 81 countries and regions. Confucius Institutes around the full use of their own advantages, to carry out a variety of teaching and cultural activities, has gradually developed a unique model, become learning Chinese language and culture, to understand an important place in contemporary China, by the local community's warm welcome.

Confucius Institute at the primary task is to meet the needs of people learning Chinese, providing them with efficient language learning resources, including language courses, Chinese teaching, Chinese teachers and so on, can be said that the Confucius Institute is the implementation of the internationalization of education. At the same time, in the general sense, the introduction of a by-product of the internationalization of teaching, the University is increasingly dependent on English language teaching, and this state of affairs for the Confucius Institute is a very good balance, so that all countries have the opportunity to students to learn a very important addition international language.

\section{Promote the Process of Internationalization of Colleges and Universities through the Spread of Chinese Learning}

Confucius Institute and other institutions to promote the language difference is that the promotion of foreign language institutions are characterized by the largest nongovernmental co-operation with relatively close, and the Confucius Institute in cooperation with the University more closely some. Confucius Institute and based on cooperation between colleges and universities, with the other body language to promote the advantages of not through the domestic and foreign institutions of higher learning colleges and universities build, Confucius Institute has been fast, efficient development. Domestic colleges and universities through the construction of the Confucius Institute to enhance their own access to a good degree of international opportunities.

Internationalization of higher education is education an important international component. International Association of Universities belong said: "Internationalization of Higher Education is to cross-border and cross-cultural point of view and atmosphere with the University's teaching, research and social services, the main functions of the process of combining It is a comprehensive process of change, changes in the existing schools as well as external changes in the school; both bottom-up, and topdown; there are school changes its policy orientation. " the internationalization of higher education, including the concept of international education, international teaching objectives, the internationalization of the teaching contents, the international exchange of personnel, the internationalization of education and so on.

(1) Gives Schools More International Exposure

Participate in the construction of the Chinese University Confucius Institute in the process, the hardware and 
software to strengthen the building of schools, and constantly improve their own quality and capacity, which is to speed up the process of internationalization of higher education an important way.

Hardware construction, the building of the Confucius Institute to participate in the colleges and universities, it is necessary to carry out effective education and teaching, research and academic exchanges, the need for the platform and place to have the corresponding conditions and equipment; in software development, participation of the staff of the International must have good language skills and cross-cultural communication skills, through the construction of the Confucius Institute can be a real internationalization of the embodiment of and promoting.

Confucius Institute of the building can enhance the school's international reputation. For example, with foreign Shandong University Confucius Institute to build the course, pay attention to the training of volunteers in Thailand, has been the first good results, so that to enhance China's international promotion of Chinese volunteers in the image, while improving of Shandong University's international image and visibility. After an international well-known colleges and universities to attract more foreign students, these students learn the language or whether it is to learn specific subject knowledge, can facilitate the process of the internationalization of colleges and universities.

Confucius Institute at the University to take the country into an important channel for international. With foreign universities to build through the Confucius Institute, the output of their teachers, and cultural as well as the management of foreign universities in the world to understand China's universities, as well as the local people learning Chinese has brought more convenient conditions. (2) Promote Inter-school All-round Cooperation and Exchanges

Confucius Institute for Chinese is not only education, but also cooperation between the two sides in scientific research, personnel, and other disciplines of the exchange platform. Confucius Institute provides an interdisciplinary platform for the different schools between disciplines, help to improve both the level of university disciplines.

Normal University in Beijing and San Francisco State University's Confucius Institute to carry out construction, "Historical Records" and Sima Qian, the modern Chinese, modern science and so on have become the San Francisco State University senior undergraduate and graduate degree programs. Beijing University since April 2006, it has been with Japan, Germany, Britain and other countries nine universities and educational institutions to the construction of the Confucius Institute and adhere to the Council system, the leadership of both parties to participate in the Council of colonel, and promote mutual exchanges and communication. Beijing is relying on this see the building of the Confucius Institute of the States to build inter-university exchanges and cooperation platform. Beijing Normal University and the University of Manchester signed an agreement to build Confucius Institute has also signed a student exchange project, the annual exchange of students to other schools of a school year. Confucius Institute opens up academic exchanges, not only the window, but also to build an interactive bridge between the international outlook has helped to build up a new talent.
At present, the functions of the Confucius Institute has gone beyond the language of teaching, can be further expanded to include disciplines and establishing infrastructure. University to build between the use of this platform for students, academic, disciplines and technical applications such as multi-faceted exchanges and cooperation.

(3) Helps Schools Take Part in international Cultural Exchanges

Confucius Institute is an opportunity for higher education exchanges. Confucius Institute in the construction process of the cooperation between colleges and universities is a process of cross-cultural communication. After completion of the Confucius Institute, cooperation and cultural exchanges between colleges and universities to carry out more vigorous.

Such as the Italian University and Chongqing University Confucius Institute has been run, greatly promote the bilateral cultural exchange. University in Italy, teachers and students can "eat" authentic "hot pot", to see the Sichuan Opera, folk music and the dragon in Sichuan, Chongqing University in Italy can also listen to "produce" a classic opera, "Confucius School building, two universities to promote international cultural exchanges directly. At the same time, the two universities have more students have the opportunity to participate in international exchanges.

\section{Conclusion}

The founding of the Confucius Institute and the internationalization of education are inextricably linked. In the context of globalization and internationalization, China must win over the understanding and support of the world. China must actively seek out opportunities to promote the Chinese language and Chinese culture. The Confucius Institute is instrumental to the internationalization of Chinese. Confucius Institutes being established in domestic and foreign universities has been extremely beneficial in the internationalization of domestic universities. Over the course of time the Confucius Institute has run into its share of problems, such as the development of teaching material to students of different cultural backgrounds and languages, and how to solve the problem of teacher shortages. These issues are worthy of our further thinking and research.

Part of this article has been published in China Adult Education (A Chinese language journal).

\section{Source of Funding}

Supported by Beijing Higher Education Young Elite Teacher Project YETP1432.

\section{References}

[1] Huang F.Transnational Higher Education:a perspective from China. Journal of Studies in International Education. 2007.

[2] Knight J. Internationalisation of higher education: A conceptual framework. In Knight, J.and deWit,H.( Ed.). Internationalisation of higher education in Asia Pacific countries.Amsterdam: European Association for International Education, 1997. 
[3] Martin J. Haigh. Internationalisation of the Curriculum: designing inclusive education for a small world. Journal of Geography in Higher Education. 2002 (1).

[4] Romuald E.J.Rudzki. The application of a strategic management model to the internationalization of higher education institutions. Higher Education. 1995 (4).
[5] Samovar L. A., R.E.Porter, L.A.Stefani. Communication between culture. 2009.

[6] http://www.hanban.org/kzxy.php. 